\title{
Combined immunodeficiency due to IL21R deficiency
}

INSERM

\section{Source}

INSERM. (1999). Orphanet: an online rare disease and orphan drug data base. Combined immunodeficiency due to IL21R deficiency. ORPHA:357329

A rare, genetic, non-severe combined immunodeficiency disorder characterized by variable B-and T-cell defects (including defective B-cell differentiation and impaired T-cell proliferation to mitogens and bacterial antigens) and natural killer cell dysfunction (rang ing from impaired cytotoxity to lymphopenia) due to IL21R deficiency, manifesting with recurrent respiratory and/or gastrointestinal tract infections and, in some cases, with severe, chronic, progressive cholangitis and liver cirrhosis associated with cryptosporidial infection. 